\title{
Quantitative diagnostics of gill diseases in common carp: not as simple as it seems
}

\author{
Mikolaj Adamek*, Felix Teitge, Dieter Steinhagen
}

Fish Disease Research Unit, Centre of Infectious Diseases, University of Veterinary Medicine, 30559 Hannover, Germany

\begin{abstract}
During a disease outbreak, affected fish exhibit particular clinical signs, and the task in veterinary diagnostics is to identify the causative agent(s) as a prerequisite for appropriate treatment measures. In this study, we present an outbreak of a multifactorial gill disease in a cohort of ornamental koi Cyprinus carpio with gill necrosis as the main exterior clinical sign. By means of pathogen identification and determining pathogen abundance in various tissues, mortality of individual fish was found to be caused by different agents. Three out of 5 diseased individuals suffered from koi herpesvirus disease (KHVD) associated with a systemic infection with cyprinid herpesvirus 3 (CyHV-3), 1 fish succumbed to koi sleepy disease (KSD) caused by a high carp edema virus (CEV) load in the gills co-infected with CyHV-3 and flavobacteria, and the last fish had low loads of both viruses but high flavobacteria and Ichthyobodo burdens and most likely died from an interaction of these bacterial and parasitic agents. The results indicated that correct identification of the agent responsible for the observed clinical signs or mortality during co-infection might require quantitative determination of the abundance of the pathogens as well as detailed knowledge of the infection biology of these pathogens.
\end{abstract}

KEY WORDS: Cyprinus carpio - Ornamental koi - Co-infection - Carp edema virus - CEV · Cyprinid herpesvirus $3 \cdot \mathrm{CyHV}-3 \cdot$ Flavobacteria $\cdot$ Ichthyobodo

\section{INTRODUCTION}

Infectious diseases can induce severe losses in aquaculture or ornamental fish populations. The pathogenicity of particular infectious agents involved in disease outbreaks in fish can be evaluated in infection experiments under controlled laboratory conditions in which the spread of the infection to different host tissues, its multiplication in the target tissue(s) and the development of clinical signs are observed. During a disease outbreak in ornamental, aquaculture or natural populations, affected fish exhibit particular clinical signs, and the task of veterinary diagnostics is to identify the causative agent(s) of the observed disease as a prerequisite for appropriate treatment measures. Identifying the causative agent(s) may be challenging because the fish may be infected with multiple pathogens, which may contribute to

${ }^{*}$ Corresponding author: mikolaj.adamek@tiho-hannover.de the observed pathology. This is especially true for mucosal tissues, where, in addition to pathogens, an imbalance of the microbiome can also contribute to pathology and clinical disease.

Gill diseases may seriously affect the health of fish because gills play a major role in their physiology. Common carp Cyprinus carpio and its ornamental variety, koi, often suffer from gill disease, with gill necrosis as a major clinical sign. Several diseases/ pathogens are associated with this pathological change. These include koi herpesvirus disease (KHVD), which is caused by a systemic infection with cyprinid herpesvirus 3 (CyHV-3) and is very often associated with a severe level of gill necrosis (Hedrick et al. 2000, Gilad et al. 2004). Gills are also the main target of carp edema virus (CEV), which causes koi sleepy disease (KSD) and is associated with a characteristic swelling of the gills but some-

() The authors 2019. Open Access under Creative Commons by Attribution Licence. Use, distribution and reproduction are unrestricted. Authors and original publication must be credited. 
times also mild gill necrosis (Way et al. 2017). Several other viruses have been isolated from necrotic gills of koi, including the spring viraemia of carp virus (SVCV) and a putative common carp paramyxovirus (CCPV) (Neukirch \& Kunz 2001). However, results from experimental infections cast doubt on whether CCPV can be the cause of severe gill pathology (Neukirch \& Kunz 2001). Also, several species of flavobacteria have been identified as pathogens associated with gill diseases; in particular, Flavobacterium branchiophilum is the causative agent of bacterial gill disease which can lead to gill necrosis and occlusion of interlamellar spaces (Wakabayashi et al. 1989). Furthermore, gill pathology could be related to parasite infections, including severe infections with the kinetoplastid flagellate Ichthyobodo necator, which causes ichthyobodiasis in several fish species (Červinka et al. 1974). Finally, poor water quality with excess amounts of ammonia, nitrite or suspended solid particles can induce gill pathology in common carp.

Recent studies have suggested that co-infections might be regularly involved in gill diseases. In Atlantic salmon Salmo salar, for instance, gill diseases were frequently recognised as multifactorial. Often simultaneous infections with ectoparasites, bacteria and the salmon gill poxvirus are found and lead to severe losses (Gjessing et al. 2017). In common carp, flavobacteria were found as secondary pathogens associated with a CEV infection and clinical KSD (Adamek et al. 2018b). Such co-infections pose severe challenges for diagnosis and treatment of gill diseases, and the outcome of co-infections may be different in individual fish because a complex interaction between the multiple factors is involved (Moore \& Jaykus 2018).

Assessing the contribution of different pathogens to the presentation and outcome of a disease is sometimes very difficult. Several factors should be included in an evaluation of possible causes of mortality in fish: (1) Clinical signs of a disease occur when a certain threshold of pathogen(s) load is reached in the tissues and the abundance of these pathogens causes pathological changes which impair tissue function. The sole presence of a particular pathogen does not necessarily imply an outbreak of a disease (NIH 2007). Therefore, in each case, in addition to their presence, the abundance of involved infectious agents should be studied. (2) Some infectious agents infect multiple organs, and the presentation of disease and mortality could be related to the synergistic effect of multi-organ failure. Therefore, when pathogens are involved, which cause a systemic infection, multiple organs should be checked. Such pathogens might cause clinical signs and organ failure at a different abundance in various tissues. This information, however, is often not available for particular fish pathogens because such data are gathered most reliably during experimental infections which associate pathological changes with a quantification of pathogen load (Zautner et al. 2017). In co-infections, interactions between different pathogens as well as the magnitude of immune responses could also influence the outcome of the disease. The interplay of these factors compounds the complexity of the diagnosis.

The development and higher accessibility of quantitative diagnostic methods have opened up new avenues to pinpoint the role of particular pathogens as causative agents of gill diseases associated with necrosis. In this study, we present an outbreak of a multifactorial gill disease in a cohort of ornamental koi from a private pond. By determining pathogen abundance, we found that in the presence of several potentially deadly pathogens in the cohort, the mortality of individual fish was most likely caused by different agents.

\section{MATERIALS AND METHODS}

\subsection{Case presentation}

The owner of a $60 \mathrm{~m}^{3}$ pond, stocked with $22 \mathrm{koi}$ and 1 goldfish, reported that fish were experiencing health problems and therefore presented 2 live fish to the consulting service of the Fish Disease Research Unit, Centre of Infectious Diseases, University of Veterinary Medicine, Hannover, Germany. The water of the pond was filtered by moving bed and drum filters and cleared by UV irradiation. The fish were fed 5 times daily with a total amount of $70 \mathrm{~g}$ of commercial feed, which constituted about $0.5 \%$ of the body weight of fish per day. About 2 mo prior to the aforementioned problems, 2 new fish, which had been purchased from a wholesaler, were introduced into the pond. During the period of 3 to $1 \mathrm{wk}$ before the consultation, 4 fish had already died (Fig. 1). The 2 fish presented to the consulting service (hereafter identified as Fish 1 and Fish 2) showed abnormal swimming behaviour and lethargy at a water temperature of $19.6^{\circ} \mathrm{C}$. At that time, clinical symptoms were reported only in original individuals from the pond population, not from the newly introduced fish. During the week following the health check, 5 fish died successively (Fish 1 to Fish 5). These included Fish 1 and Fish 2 which had been presented to the consult- 


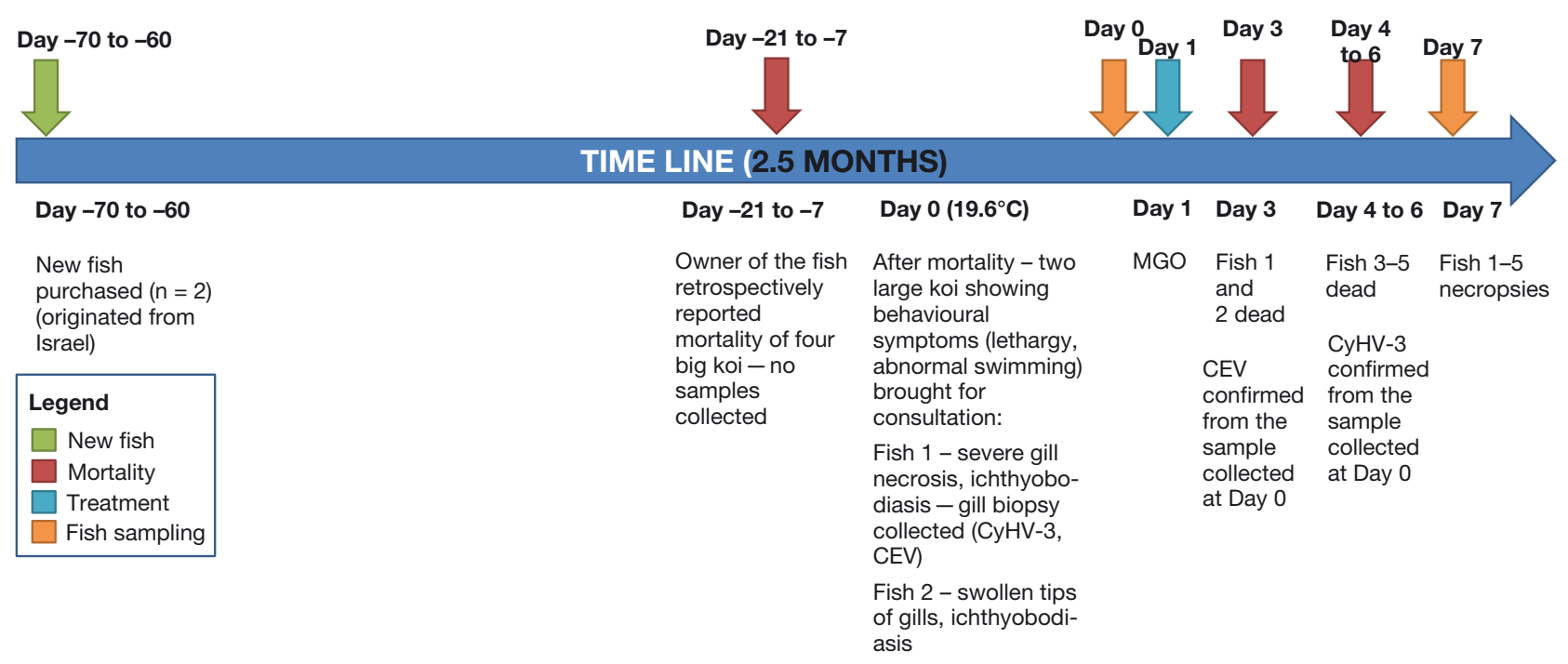

Fig. 1. Time line of the case study. Indicated are the purchases of new fish, mortality events, presentation of fish to the consulting service, collection of samples from the fish and the application of treatments. MGO: malachite green oxalate (treatment administered)

ing service several days earlier. The dead fish were collected in separate plastic bags, frozen and kept at $-20^{\circ} \mathrm{C}$ for less than $1 \mathrm{wk}$ and then submitted for necropsy and further examination (Fig. 1). No further fish with clinical signs were reported by the owner afterwards.

\subsection{Sample processing}

During the health check, skin and gill scrapings were collected from Fish 1 and Fish 2 as well as a small biopsy of necrotic gill tissue from Fish 1. The sample collection was carried out under narcosis with $150 \mathrm{mg} \mathrm{l}^{-1}$ buffered MS-222 from the distal part of the gill lamellae and from 3 locations of the skin: the areas covered by the pelvic and pectoral fins and a lateral $1 \mathrm{~cm}^{2}$ part under the back fin. The scrapings were observed as fresh mounts under a light microscope, and the gill tissue sample was subjected to DNA extraction and subsequent $\mathrm{CEV} / \mathrm{CyHV}-3$ diagnostics.

During necropsy of the 5 fish which had died during the week following the initial consultation, samples of the gill, fin, brain, kidney, head kidney, liver, end gut, spleen and heart were collected. These samples were also subjected to DNA extraction. DNA was extracted twice from gill samples. The gill samples were also inoculated into Cyprinus carpio brain cell (CCB) cell monolayers, in accordance with a routine protocol (Ganzhorn \& LaPatra 1994). As frozen fish were submitted for diagnostics, only samples for molecular biological examinations and cell culturing could be collected, and no bacteriological and histological examinations were performed. The samples were collected from the frozen fish immediately after their arrival to the laboratory.

\subsection{Quantitative PCR (qPCR)}

Genomic DNA was extracted from all tissues using the QIAamp DNA mini kit (Qiagen) in accordance with the manufacturer's instructions. Total RNA from gill and kidney samples was isolated with Tri-Reagent (Sigma) and transcribed to cDNA with the Maxima First Strand cDNA Synthesis Kit (Thermo Fisher Scientific) in accordance with the manufacturer's instructions. qPCRs for detecting DNA specific for CyHV-3, $\mathrm{CEV}$ and flavobacteria were performed as described earlier (Gilad et al. 2004, Adamek et al. 2013, 2018b). A qPCR for detecting Ichthyobodo necator-specific DNA sequences was adopted from Isaksen et al. (2012), but instead of a probe-based detection of specific DNA sequences, SYBR Green was used. Reverse transcriptase (RT-)qPCR for detecting SVCV and CCPV were performed with SYBR Green-based detection of amplicons. The SYBR Green assay was also used for detecting a new, currently not characterised, cyprinid herpesvirus (nCyHV) (authors' unpubl. obs.). Nucleotide sequences for all primers are presented in Table 1. All results are presented as copy numbers of pathogen-specific DNA per 250 ng of DNA/RNA isolated from each of the samples. CEV and CyHV-3 qPCR were run for all samples, while Ichthyobodo, flavobacteria and nCyHV PCRs were run for gills, fins and kidneys. SVCV and CCPV RT-qPCR were run only for cDNA obtained from gills and kidneys. 
Table 1. Sequences of primers used in quantitative PCR (qPCR) for detecting DNA of cyprinid herpesvirus 3 (CyHV-3), carp edema virus (CEV), non-characterised cyprinid herpesvirus (nCyHV), flavobacteria and Ichthyobodo and the RT-qPCR for detecting RNA of spring viraemia of carp virus (SVCV) and common carp paramyxovirus (CCPV)

\begin{tabular}{|c|c|c|c|c|c|}
\hline Pathogen & Primer/probe name & Primer/probe sequence $\left(5^{\prime}-3^{\prime}\right)$ & Template & Detection & Reference \\
\hline CyHV-3 & $\begin{array}{l}\text { KHV-86F } \\
\text { KHV-163R } \\
\text { KHV-109P }\end{array}$ & $\begin{array}{c}\text { GAC GCC GGA GAC CTT GTG } \\
\text { CGG GTT CTT ATT TTT GTC CTT GTT } \\
\text { [FAM]-CTT CCT CTG CTC GGC GAG } \\
\text { CAC G-[BHQ1] }\end{array}$ & DNA & Probe & $\begin{array}{l}\text { Gilad et al. } \\
\text { (2004) }\end{array}$ \\
\hline CEV & $\begin{array}{c}\text { CEFAS_qF } \\
\text { CEFAS_qR } \\
\text { CEFAS_q_Probe }\end{array}$ & $\begin{array}{c}\text { AGT TTT GTA KAT TGT AGC ATT TCC } \\
\text { GAT TCC TCA AGG AGT TDC AGT AAA } \\
\text { [FAM]-AGA GTT TGT TTC TTG CCA TAC } \\
\text { AAA CT-[BHQ1] }\end{array}$ & DNA & Probe & $\begin{array}{l}\text { Matras et al. } \\
(2017)\end{array}$ \\
\hline SVCV & $\begin{array}{l}\text { SVCV_G_qF } \\
\text { SVCV_G_qR }\end{array}$ & $\begin{array}{c}\text { GCT ACA TCG CAT TCC TTT TGC } \\
\text { GCT GAA TTA CAG GTT GCC ATG AT }\end{array}$ & RNA & $\begin{array}{l}\text { SYBR } \\
\text { Green }\end{array}$ & $\begin{array}{l}\text { García-Valtanen } \\
\text { et al. (2014) }\end{array}$ \\
\hline CCPV & $\begin{array}{l}\text { Carp_Para_qF1 } \\
\text { Carp_Para_qR1 }\end{array}$ & $\begin{array}{l}\text { TGG TTG GGA TAC TGG AGT GG } \\
\text { TCC TCT TCC TAC GGG GCT TT }\end{array}$ & RNA & $\begin{array}{l}\text { SYBR } \\
\text { Green }\end{array}$ & $\begin{array}{l}\text { Rakus et al. } \\
\text { (2019) }\end{array}$ \\
\hline nCyHV & $\begin{array}{l}\text { nCyHV_Pol_qF1 } \\
\text { nCyHV_Pol_qR1 }\end{array}$ & $\begin{array}{l}\text { CCA GCA ACA TGG AGG CCG TGC } \\
\text { GTG TAG GTG ACG AAC CGC GT }\end{array}$ & DNA & $\begin{array}{l}\text { SYBR } \\
\text { Green }\end{array}$ & Present study \\
\hline Flavobacteria & $\begin{array}{l}\text { Flav_16s_qF1 } \\
\text { Flav_16s_qR1 }\end{array}$ & $\begin{array}{l}\text { GGG ATA GCC CAG AGA AAT TTG GAT } \\
\text { AGT CTT GGT AAG CCG TTA CCT T }\end{array}$ & DNA & $\begin{array}{l}\text { SYBR } \\
\text { Green }\end{array}$ & $\begin{array}{l}\text { Adamek et al. } \\
(2013)\end{array}$ \\
\hline Ichthyobodo & $\begin{array}{l}\text { Costia F } \\
\text { Costia R }\end{array}$ & $\begin{array}{c}\text { ACG AAC TTA TGC GAA GGC A } \\
\text { TGA GTA TTC ACT YCC GAT CCA T }\end{array}$ & DNA & $\begin{array}{l}\text { SYBR } \\
\text { Green }\end{array}$ & $\begin{array}{l}\text { Isaksen et al. } \\
(2012)\end{array}$ \\
\hline
\end{tabular}

\subsection{Identification of the pathogens}

During microscopic examination, the parasites were identified on the basis of morphological and behavioural characteristics. For molecular biological identification, the nucleotide sequences of the PCR amplicons were obtained by Sanger's sequencing performed by LGC Genomic (Berlin). These amplicons were obtained with end-point PCRs using the KAPA 2G HotStart PCR Kit and primers listed in Table 1. The DNA sequence of the PCR amplicon of the P4a core protein of CEV (357 bp) and the PCR amplicon of a fragment of open reading frame (ORF) 72 of CyHV-3 (820 bp) were used for phylogenetic analyses performed with tools available at www. phylogeny.fr. The identification of flavobacteria was performed by molecular cloning of a fragment of the 16S rRNA gene specific for flavobacteria as described earlier (Adamek et al. 2018b).

\section{RESULTS}

\subsection{Observations on live fish - Day 0}

Fish 1 presented severe gill necrosis on the left side of the body. In most of the gill arches (3 out of 4), $20-25 \%$ of the gill tissue was necrotic. The remaining area of the gills appeared unchanged. In gill scrapings, medium amounts of Ichthyobodo cells (5-10 specimens per microscopic field at 200× magnifica- tion) were found, while in the skin scrapings, a high amount of Ichthyobodo (more than 10 specimens per microscopic field) and low amounts of Trichodina cells (a small number of specimens in the sample) were noted. The mucus level on the skin and gills was slightly increased. Fish 1 also displayed slightly sunken eyes. Fish 2 presented swollen gills and a parasite burden similar to Fish 1. In order to lower the ectoparasite burden, a malachite green oxalate (MGO) treatment, without any further active substances (Cyprinocur, Dr. K. Hollborn \& Söhne, Leipzig) was prescribed at a concentration of $0.06 \mathrm{mg} \mathrm{l}^{-1}$ to be applied every second day to pond water.

\subsection{Water quality}

Several water quality parameters were measured: temperature $19.6^{\circ} \mathrm{C}, \mathrm{pH} 7.4, \mathrm{NH}_{4}=0.09 \mathrm{mg} \mathrm{l}^{-1}, \mathrm{NO}_{2}=$ $0.06 \mathrm{mg} \mathrm{l}^{-1}, \mathrm{NO}_{3}=1.0 \mathrm{mg} \mathrm{l}^{-1}$, total hardness = $2.31 \mathrm{mmol} \mathrm{l}^{-1} \mathrm{CaCO}_{3}$ equivalents), carbonate hardness $=1.96 \mathrm{mmol} \mathrm{l}^{-1} \mathrm{CaCO}_{3}$.

\subsection{Molecular biological analysis of gill samples collected during consultation}

Molecular biological analysis of the gill samples collected intra vitam from Fish 1 during the consultation revealed an infection of the gills with $5.2 \times 10^{6}$ copies of CEV-specific DNA, $1.17 \times 10^{5}$ copies of CyHV-3- 

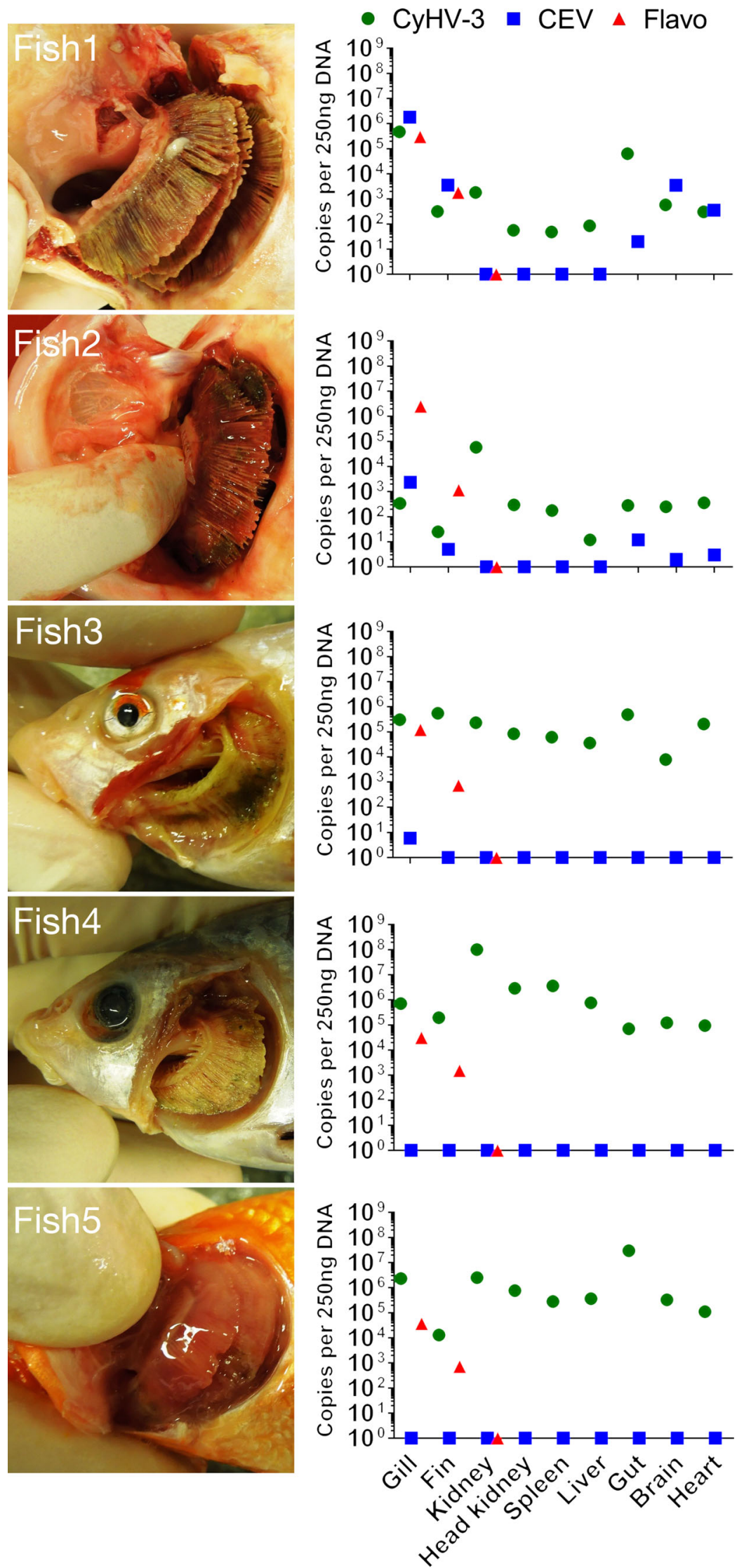

specific DNA, $4.19 \times 10^{4}$ copies of flavobacteria-specific DNA sequences and $4.3 \times 10^{1}$ copies of Ichthyobodospecific DNA sequences. These data demonstrated that the fish had experienced a co-infection with the pathogenic viruses CEV and CyHV-3.

\subsection{Quantitative evaluation of pathogens in tissues of deceased fish}

In order to further analyse the coinfection of the fish with CEV and CyHV-3, samples from the 5 deceased fish were collected and examined by means of molecular biological methods. Macroscopically severe gill necrosis was evident in most individuals (Fig. 2). The gills of Fish 5 were the least affected, with only a relatively small necrotic spot on the left side of the body. Gills and kidneys from all fish were negative for SVCV and CCPV RNA and nCyHV DNA (Table 2).

3.4.1. Fish 1. Gills of Fish 1 post mortem harboured $4.68 \times 10^{5}$ copies of CyHV-3-specific DNA, $1.83 \times 10^{6}$ copies of CEV-specific DNA and 3.03 $\times 10^{5}$ copies of flavobacterial DNA, while no Ichthyobodo DNA was detected (Fig. 2, Table 2). To avoid a possible misinterpretation of the pathogen load in gills, resulting from a possibly patchy distribution of the pathogens in the tissue, DNA was extracted from another gill sample and analysed for a second time. This confirmed the high CEV load and a lower

Fig. 2. Presentation of pathological signs and pathogen load of sampled fish. Left column: Pictures of the gills of diseased fish taken during necropsy. Right column: Results from the qPCRs for DNA of cyprinid herpesvirus 3 (CyHV-3), carp edema virus (CEV) and flavobacteria (Flavo). Presented are pathogen loads from the first gill sample and additional organs (fin, kidney, head kidney, spleen, liver, gut, brain and heart) collected during necropsies. Pathogen loads are presented as copy numbers from plasmid-based quantification per $250 \mathrm{ng}$ of DNA isolated from the tissue library of each individual 


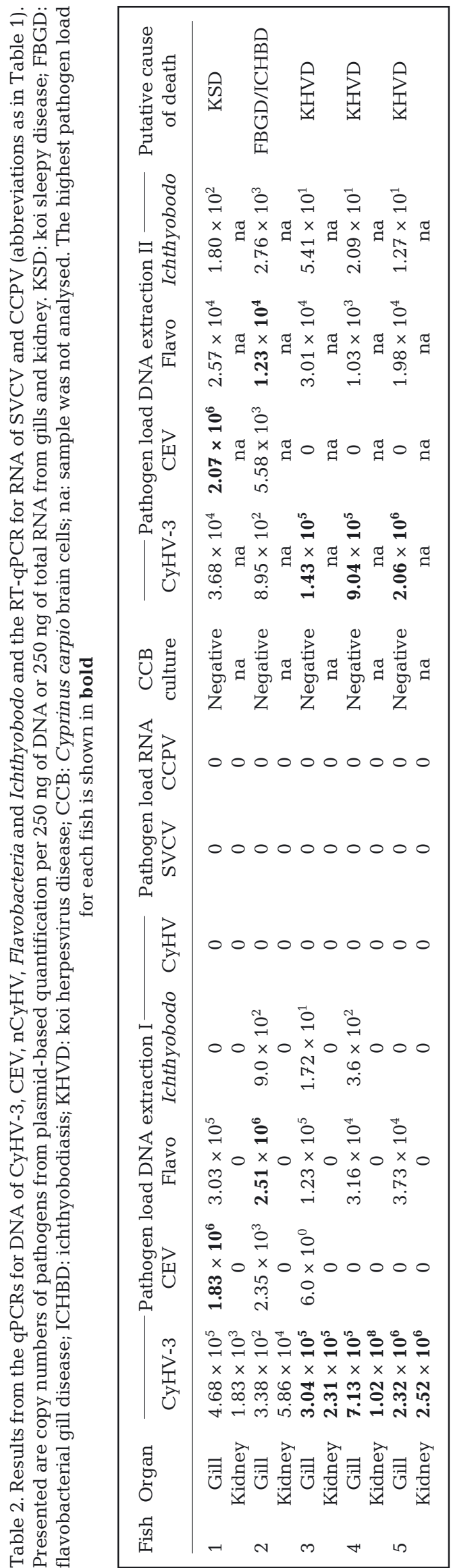

abundance of CyHV-3 and flavobacteria. In this second analysis, $1.80 \times 10^{2}$ copies of Ichthyobodo DNA were detected (Fig. 2). In this fish, CEV was also found in fin and brain samples with $>10^{3}$ copies, while the gut and heart harboured a lower amount of the virus. CyHV-3 was detected in all organs but in a lower abundance than in the gills. The gut and kidney harboured $10^{3}$ to $10^{4}$ copies of this virus (Fig. 2). All other organs had lower virus loads, with the head kidney, spleen and liver harbouring $10^{2}$ to $10^{3}$ copies. Flavobacteria were detected in the fins in a lower abundance than in the gills, at a concentration of about $10^{3}$ copies of specific DNA.

3.4.2. Fish 2. In the gills of Fish 2 , we found low numbers of CyHV-3 $\left(3.38 \times 10^{2}\right.$ copies $), \mathrm{CEV}(2.35 \times$ $10^{3}$ copies) and Ichthyobodo $\left(9.0 \times 10^{2}\right.$ copies $)$, but a high load of flavobacteria $\left(2.51 \times 10^{6}\right.$ copies) (Fig. 2, Table 2). The second gill sample of Fish 2 harboured an elevated level of about $10^{3}$ copies Ichthyobodo DNA. Furthermore, in this sample, lower amounts of flavobacteria were found, with $10^{4}$ to $10^{5}$ copies (Table 2). The screening of the other organs indicated a low CyHV-3 load of about $10^{3}$ copies; only the kidney harboured about $10^{4}$ copies of CyHV-3-specific DNA. CEV DNA was barely detectable in the fin, gut, brain and heart. Flavobacteria were detected in the fins $\left(1.15 \times 10^{3}\right.$ copies) but not in the kidney (Fig. 2).

3.4.3. Fish 3. In gills of Fish $3,3.04 \times 10^{5}$ copies of CyHV-3, 6 copies of CEV, $1.23 \times 10^{5}$ copies of flavobacteria and 17 copies of Ichthyobodo-specific DNA were detected. In the second gill sample, CEV was not detected (Fig. 2, Table 2). In other organs, the abundance of CyHV-3 dominated, with about $10^{5}$ copies of virus in the fins, kidney and heart. The head kidney, spleen and liver contained about $10^{4}$ copies and the brain about $10^{3}$ copies of CyHV-3 DNA. CEV could not be detected in any other organ besides the gills. Flavobacteria were found in the fins at about $10^{3}$ copies (Fig. 2).

3.4.4. Fish 4. All organs of Fish 4 were CEV negative, and the gills harboured $7.13 \times 10^{5}$ copies of CyHV-3, $3.16 \times 10^{4}$ copies of flavobacteria and $3.6 \times$ $10^{2}$ copies of Ichthyobodo-specific DNA, respectively. From the second gill sample, very similar results were obtained (Fig. 2, Table 2). Some of the internal organs had very high loads of CyHV-3, with the kidney having about $10^{8}$ copies and the head kidney and spleen about $10^{6}$. All other organs had about $10^{4}$ copies of CyHV-3 DNA (Table 2).

3.4.5. Fish 5. In the gills of Fish 5, only DNA specific for CyHV-3 (2.32 × $10^{6}$ copies) and for flavobacteria $\left(3.73 \times 10^{4}\right.$ copies $)$ could be found. In the second gill sample, Ichthyobodo DNA was also detected (Fig. 2, 
Table 2). In other organs, the highest number of CyHV-3 DNA was found in the gut $\left(2.99 \times 10^{7}\right.$ copies $)$ and kidney $\left(2.52 \times 10^{6}\right.$ copies $)$. All internal organs were infected with about $10^{5}$ copies of this virus. In the fins, CyHV-3 and flavobacteria were detected at an abundance of $1.31 \times 10^{4}$ and $7.29 \times 10^{2}$ copies, respectively (Fig. 2).

\subsection{Phylogenetic analysis of CEV and $\mathrm{CyHV-3}$ isolates}

The phylogenetic analysis of the CEV isolate from Fish 1 confirmed that this virus was from Genogroup IIa (Matras et al. 2017) and was closely related to viruses found in koi from Germany and in common carp from Hungary (Adamek et al. 2018a). The phylogenetic tree also shows a close relation to Japanese and Chinese isolates from koi and common carp (Fig. 3).

Due to the low variability in the nucleotide sequence of CyHV-3-specific DNA between the isolates, we concluded that the CyHV-3 isolate, which most likely caused the mortality in Fish 3-5, clustered with European isolates of this virus (Fig. 4).

\subsection{Flavobacteria identification}

Gills of Fish 2 harboured the highest number of flavobacteria, even though the bacteria were not registered during microscopic examination of gill scrapings. Molecular cloning indicated the presence of a mixed infection with Flavobacterium succinicans, F. sasangense and some other unidentified uncultured bacteria in gill samples from this fish.

\subsection{Cell cultures}

CCB cells inoculated with medium supernatant collected after homogenisation of the gill samples showed only mild morphological changes which could not be re-passaged to a new culture. Therefore, results from the cell-based method for detecting viruses were concluded to be negative.

Fig. 3. Phylogenetic analysis of the nucleotide sequence encoding the carp edema virus (CEV) P4a core protein. This analysis presents CEV sequences obtained from Fish 1 during this study, as well as sequences from fish from Poland (PL), the UK, Hungary (HU), Serbia (SER), Germany (D), China (C), South Korea (Korea) and Japan (J). The branch length is proportional to the number of nucleotide substitutions per site

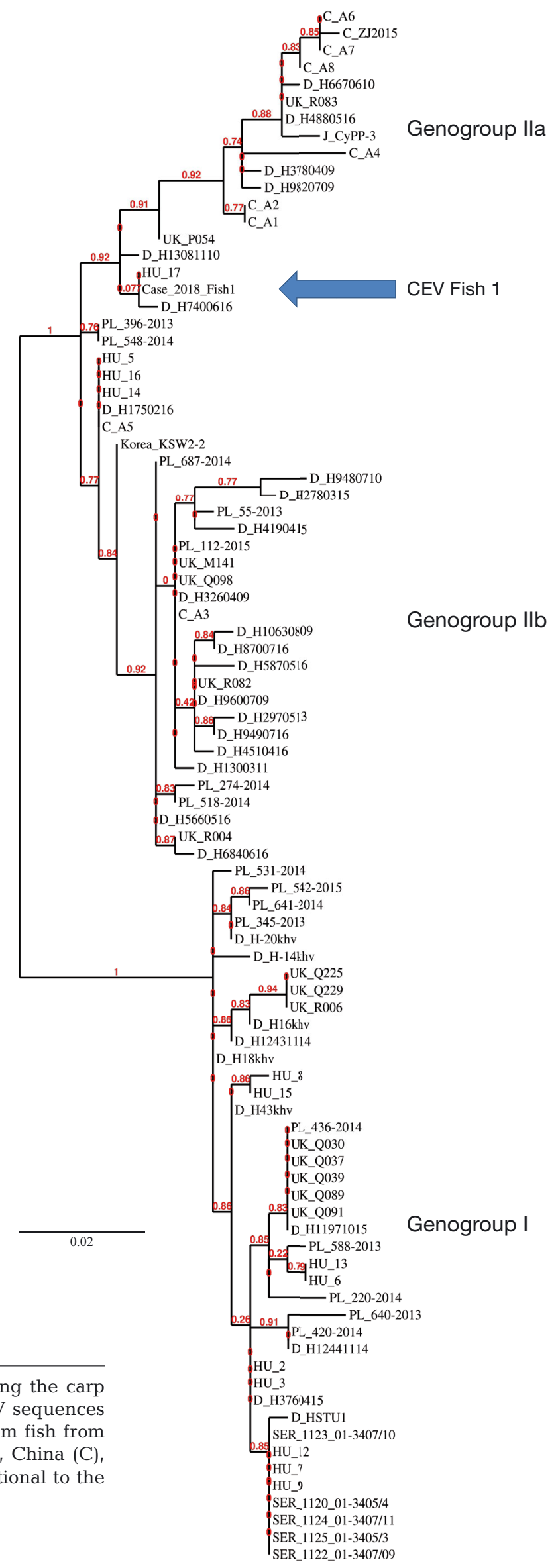




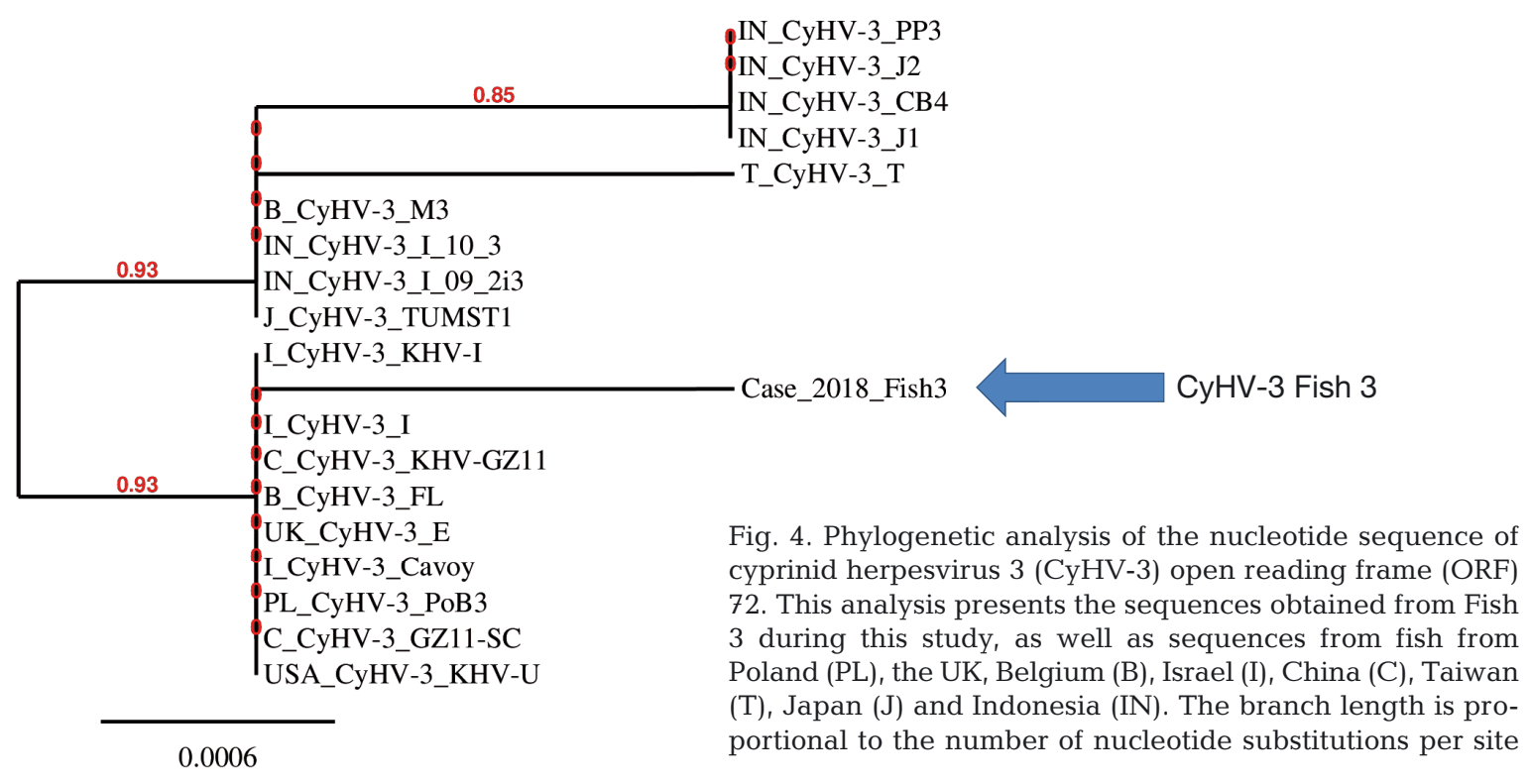

\subsection{Putative diagnosis}

Based on the quantitative determination of pathogen abundance, the following putative diagnosis can be given for individual fish: Fish 1 most likely died from KSD caused by an infection with CEV. In this fish, flavobacteria and CyHV-3 were most likely secondary pathogens. With the highest Ichthyobodo and flavobacteria burdens, the death of Fish 2 was presumably caused by both the flavobacterial infection and ichthyobodiasis. Fish 3-5 died from KHVD caused by a systemic infection with CyHV-3.

\section{DISCUSSION}

This case study was carried out with the aim of unravelling the impact of several virulent pathogens present in a cohort of ornamental koi on the development of clinical gill necrosis and mortality in individual fish. By applying quantitative methods to determine pathogen abundance in several tissues of infected fish, it could be shown that in individual fish the clinical syndrome gill necrosis and mortality were most likely caused by different agents. This was suggested earlier by Neukirch \& Kunz (2001), who isolated multiple viruses from koi with gill necrosis, including one of the first isolations of CyHV-3, several stillincompletely characterised paramyxo-, orthomyxoand birna/reo-viruses of common carp, as well as SVCV (Neukirch \& Kunz 2001).

Because the fish in our study came from the same cohort, co-infections with the same pathogens, in- cluding several potentially highly virulent pathogens, were found in the gills and other organs of individual fish. However, based on dominance and distribution of the pathogens, different putative diagnoses for mortality were achieved for the individual fish. Crucial for the evaluation of pathogen abundance findings were results from experimental infections. In these studies, the abundance of particular pathogens is determined in various tissues and correlated to clinical signs of disease. For example, KHVD is an outcome of a systemic infection of carp with CyHV-3, with the virus present in high abundance (threshold $>10^{5}$ ) in multiple organs (Gilad et al. 2004, TadmorLevi et al. 2017, Adamek et al. 2019). Therefore, in the present case, KHVD was relatively easily determined as the cause of mortality in Fish 3-5. In these individuals, a systemic infection and high CyHV-3 abundance were confirmed in most of the examined tissues.

Taking into account the different tissue tropism of CEV and CyHV-3 and the threshold loads for these viruses which lead to clinical signs, Fish 1 had most likely suffered from KSD caused by CEV. In this fish, gills harboured the highest amount of CEV ( $>10^{6}$ copies per $250 \mathrm{ng}$ DNA), and a CEV load at the threshold level $>10^{4}$ was related to mortality in previous infection experiments and field studies (Adamek et al. 2016, 2017, 2018b). In this fish, CyHV-3 and gill infection with flavobacteria could be treated as co-infecting agents but not as primary causes of mortality. The high load of CyHV-3 in gills but not in internal organs suggests that this fish was in a subclinical phase of the 
CyHV-3 infection (Gilad et al. 2004, Tadmor-Levi et al. 2017).

The results from Fish 2 are the most puzzling because this individual had low loads of both viruses in the target tissues. However, the flavobacterial load of $>10^{6}$ in the gill samples could indicate a putative flavobacterial gill disease, which, with an involvement of Ichthyobodo, could have contributed to the clinical signs. Flavobacteria are known pathogens causing gill disease. Results from field samples and from infection experiments indicate that the bacterial load recorded in Fish 2 could be related to an advanced stage of flavobacterial infection and not to the natural microbiome of common carp gills which harbours $<10^{2}$ of these bacteria (Adamek et al. 2018b). However, the identified flavobacteria species are not known to be pathogens of common carp. This might indicate that in this fish, opportunistic commensals increased in number during an Ichthyobodo infection (Adamek et al. 2018b), which in itself is also not a deadly parasite of carp but might become clinically relevant in carp under additional challenges. Both pathogens appeared to be distributed on the gills in patches, because the abundance determined for these pathogens differed between the samples analysed and therefore appeared to be influenced by the particular fragment of the collected organ. Furthermore, the influence of treating the carp with MGO on the development of the virus infections remains unclear. The treatment most likely induced a shift in the external microbiome, as was observed after an application of potassium permanganate which subsequently increased the susceptibility of the treated fish to columnaris disease, induced by Flavobacterium columnare (Mohammed \& Arias 2015). Hence, in the present case, the MGO treatment might have fostered the flavobacteria development in Fish 2. During microscopic examination of gill samples from this fish, flavobacteria were not observed, but after MGO treatment, a high amount of flavobacteria-specific DNA was recorded in gill samples from the same fish.

When the fish were first presented for health consultation, we did not expect the co-existence of 3 to 4 different disease-causing pathogens in the examined cohort of fish, which then caused the death of 5 fish during the following $4 \mathrm{~d}$. From all pathogens observed during the current case, the infections with CyHV-3 and KHVD subsequently caused by this virus seem to be the most severe. The virulence of this virus in carp and koi is well known, and high mortalities were recorded in various infection experiments (Rakus et al. 2009, Ødegård et al. 2010, Piačková et al. 2013). Many internal organs besides gills and skin are suitable (Gilad et al. 2004) for detecting this virus for diagnostic purposes. Therefore, for differential diagnosis of KHVD/CyHV-3 and KSD/CEV, besides gills, which are the main target tissue for $\mathrm{CEV}$, internal organs should be examined as well. When a fish is suffering from KHVD in addition to a CEV infection, the CyHV-3 virus load in the internal organs is expected to be equal to or higher than in the gills (Gilad et al. 2004, Tadmor-Levi et al. 2017, Adamek et al. 2019). Based on the scarce literature on CEV infections and the findings in our infection experiments, primarily gills would be positive for CEV in fish suffering from KSD. In these fish, CEV could be found in internal organs but at a rather low abundance in comparison to the gills (Adamek et al. 2017).

CyHV-3 and CEV co-infections were previously described from a koi cohort in China (Ouyang et al. 2018). Those authors presented very puzzling results. In contrast to previous reports on the infection biology of these 2 viruses, they observed the highest CEV virus loads in the kidney (mean of $8.46 \times 10^{6}$ copies) with a lower abundance in the gills $\left(4.52 \times 10^{6}\right.$ copies). Despite the presence of several pathological changes characteristic for KHVD, such as ulcerative skin lesions and necrotic changes in the kidney and liver, a much lower abundance of CyHV-3 in the gills $\left(1.58 \times 10^{4}\right.$ copies $)$ and $1.19 \times 10^{2}$ copies was seen in the kidney compared to CEV (Ouyang et al. 2018). Although the infection dynamics of viruses can be very divergent in individual fish, even during standardised infections performed in the laboratory setup, the tissue tropism is expected to be more stable for each of the viruses (Baron et al. 1996). Prior publications on CEV provide no evidence for a high abundance of this virus in the kidney of infected fish (Oyamatsu et al. 1997, Miyazaki et al. 2005, Adamek et al. 2017). Results from tissue libraries and samples collected from natural outbreaks of KSD clearly showed that gills are the main target tissue of CEV (Oyamatsu et al. 1997, Miyazaki et al. 2005, Adamek et al. 2017). Results from the present study, as well as from several additional experimental infections (authors' unpubl. data) also do not provide evidence for the kidney being a target tissue for CEV and suggest comparing the virus load in the gills and kidney for a differential diagnosis of KHVD and KSD in case of co-infection.

Besides the report from China and the current case study, CEV/CyHV-3 co-infections have yet to be reported. During a screening of tissue samples of carp and koi from Austria, Hungary and Serbia, which showed gill pathology, only single infections with 
CEV or CyHV-3 were detected (Lewisch et al. 2015, Adamek et al. 2018a, Radosavljevic et al. 2018). These results could have been partly related to the different temperature range of the viruses. In Europe, CEV from Genogroup I is mainly present in common carp, and this virus seems to be able to infect carp and cause disease at a temperature range of $10-12^{\circ} \mathrm{C}$, which is well below the temperature range of $18-$ $28^{\circ} \mathrm{C}$ for clinical outbreaks of diseases caused by CyHV-3. CEV from Genogroup IIa caused infections and clinical disease at a lower range of temperature of $11-16^{\circ} \mathrm{C}$ as well (Adamek et al. 2017, 2018b). Nonetheless, results from Japan and India indicate that infection with this virus is also capable of causing clinical signs at temperatures ranging from 19 to $24^{\circ} \mathrm{C}$ (Oyamatsu et al. 1997, Miyazaki et al. 2005, Swaminathan et al. 2016). In the present case, the temperature of the pond water was $\sim 20^{\circ} \mathrm{C}$ during the outbreak of the clinical disease, which apparently was within the permissive temperature range of both viruses.

Our results show that in disease situations with the presence of several virulent pathogens, a qualified diagnosis of the cause of a clinical disease cannot be based on the confirmation of the presence of a particular pathogen in one organ of an affected fish. In most cases, a quantification of the abundance of the pathogens is required. On the other hand, the approach of our present study, in which an array of different tissues was examined, is very resource consuming. According to our current price list, the total costs for the examinations carried out in our study exceeded 700 Euro plus tax per fish and the analysis took several working days and could not be applied routinely. Due to the access of frozen material only, no histological analyses were performed, which impaired our diagnosis as we were unable to compare molecular biological data on the abundance of the pathogens with histopathological changes in infected tissues. Furthermore, combining samples from several sites from gills for determination of pathogen abundance could improve the quantitative analyses which can be affected by a patchy distribution of the selected pathogens. This approach together with histology could lower the end-cost of the analyses.

In conclusion, the presence of multiple virulent pathogens in a cohort of fish could be challenging when attempting to obtain a correct diagnosis and confirm the pathogen responsible for the clinical signs and mortality. This requires a quantitative approach when determining the abundance of the pathogens present and detailed knowledge of the infection biology.

\section{LITERATURE CITED}

Adamek M, Syakuri H, Harris S, Rakus KŁ and others (2013) Cyprinid herpesvirus 3 infection disrupts the skin barrier of common carp (Cyprinus carpio L.). Vet Microbiol 162: 456-470

Adamek M, Jung-Schroers V, Hellmann J, Teitge F and others (2016) Concentration of carp edema virus (CEV) DNA in koi tissues affected by koi sleepy disease (KSD). Dis Aquat Org 119:245-251

Adamek M, Oschilewski A, Wohlsein P, Jung-Schroers V and others (2017) Experimental infections of different carp strains with the carp edema virus (CEV) give insights into the infection biology of the virus and indicate possible solutions to problems caused by koi sleepy disease (KSD) in carp aquaculture. Vet Res 48:12

* Adamek M, Baska F, Vincze B, Steinhagen D (2018a) Carp edema virus from three genogroups is present in common carp in Hungary. J Fish Dis 41:463-468

Adamek M, Teitge F, Jung-Schroers V, Heling M and others (2018b) Flavobacteria as secondary pathogens in carp suffering from koi sleepy disease. J Fish Dis 41:1631-1642

Adamek M, Matras M, Dawson A, Piackova V and others (2019) Type I interferon responses of common carp strains with different levels of resistance to koi herpesvirus disease during infection with CyHV-3 or SVCV. Fish Shellfish Immunol 87:809-819

Baron S, Fons M, Albrecht T (1996) Viral pathogenesis. In: Baron S (ed) Medical microbiology, $4^{\text {th }}$ edn. University of Texas Medical Branch at Galveston, Galveston, TX

光ervinka S, Vítovec J, Lom J, Hoška J, Kubů F (1974) Dermocystidiosis-a gill disease of the carp due to Dermocystidium cyprini n.sp. J Fish Biol 6:689-699

Ganzhorn J, LaPatra SE (1994) General procedures for virology. In: Thoesen JC (ed) Fish health blue book, Number 4: Suggested procedures for the detection and identification of certain finfish and shellfish pathogens. American Fisheries Society, Bethesda, MD

* García-Valtanen P, Martinez-Lopez A, Ortega-Villaizan M, Perez L, Coll JM, Estepa A (2014) In addition to its antiviral and immunomodulatory properties, the zebrafish $\beta$-defensin 2 (zfBD2) is a potent viral DNA vaccine molecular adjuvant. Antiviral Res 101:136-147

Gilad O, Yun S, Zagmutt-Vergara FJ, Leutenegger CM, Bercovier H, Hedrick RP (2004) Concentrations of a Koi herpesvirus (KHV) in tissues of experimentally infected Cyprinus carpio koi as assessed by real-time TaqMan PCR. Dis Aquat Org 60:179-187

Gjessing MC, Thoen E, Tengs T, Skotheim SA, Dale OB (2017) Salmon gill poxvirus, a recently characterized infectious agent of multifactorial gill disease in freshwater- and seawater-reared Atlantic salmon. J Fish Dis 40:1253-1265

*Hedrick RP, Gilad O, Yun S, Spangenberg JV and others (2000) A herpesvirus associated with mass mortality of juvenile and adult koi, a strain of common carp. J Aquat Anim Health 12:44-57

* Isaksen TE, Karlsbakk E, Repstad O, Nylund A (2012) Molecular tools for the detection and identification of Ichthyobodo spp. (Kinetoplastida), important fish parasites. Parasitol Int 61:675-683

Kewisch E, Gorgoglione B, Way K, El-Matbouli M (2015) Carp edema virus/koi sleepy disease: an emerging disease in Central-East Europe. Transbound Emerg Dis 62: $6-12$ 
Matras M, Borzym E, Stone D, Way K and others (2017) Carp edema virus in Polish aquaculture - evidence of significant sequence divergence and a new lineage in common carp Cyprinus carpio (L.). J Fish Dis 40:319-325

Miyazaki T, Isshiki T, Katsuyuki H (2005) Histopathological and electron microscopy studies on sleepy disease of koi Cyprinus carpio koi in Japan. Dis Aquat Org 65:197-207

Mohammed HH, Arias CR (2015) Potassium permanganate elicits a shift of the external fish microbiome and increases host susceptibility to columnaris disease. Vet Res 46:82

Moore MD, Jaykus LA (2018) Virus-bacteria interactions: implications and potential for the applied and agricultural sciences. Viruses 10:61

Neukirch M, Kunz U (2001) Isolation and preliminary characterization of several viruses from koi (Cyprinus carpio) suffering gill necrosis and mortality. Bull Eur Assoc Fish Pathol 21:125-135

NIH (National Institutes of Health) (2007) Understanding emerging and re-emerging infectious diseases. Biological Sciences Curriculum Study NIH Curriculum Supplement Series. NIH, Bethesda, MD

$\varnothing$ degård J, Olesen I, Dixon P, Jeney Z and others (2010) Genetic analysis of common carp (Cyprinus carpio) strains. II: Resistance to koi herpesvirus and Aeromonas hydrophila and their relationship with pond survival. Aquaculture 304:7-13

Ouyang P, Yang R, Chen J, Wang K and others (2018) First detection of carp edema virus in association with cyprinid herpesvirus 3 in cultured ornamental koi, Cyprinus carpio L., in China. Aquaculture 490:162-168

*yamatsu T, Hata N, Yamada K, Sano T, Fukuda H (1997) An etiological study on mass mortality of cultured colorcarp juveniles showing edema. Fish Pathol 32:81-88

Piačková V, Flajšhans M, Pokorová D, Reschová S, Gela D, Čížek A, Veselý T (2013) Sensitivity of common carp,

Editorial responsibility: James Jancovich,

San Marcos, California, USA
Cyprinus carpio L., strains and crossbreeds reared in the Czech Republic to infection by cyprinid herpesvirus 3 (CyHV-3; KHV). J Fish Dis 36:75-80

* Radosavljevic V, Adamek M, Milicevic V, Maksimovic-Zoric J, Steinhagen D (2018) Occurrence of two novel viral pathogens (CEV and CyHV-2) affecting Serbian cyprinid aquaculture and ichthyofauna. J Fish Dis 41:851-854

Kakus KE, Wiegertjes GF, Adamek M, Siwicki AK, Lepa A, Irnazarow I (2009) Resistance of common carp (Cyprinus carpio L.) to Cyprinid herpesvirus-3 is influenced by major histocompatibility (MH) class II B gene polymorphism. Fish Shellfish Immunol 26:737-743

Rakus K, Adamek M, Mojżesz M, Podlasz P and others (2019) Evaluation of zebrafish (Danio rerio) as an animal model for the viral infections of fish. J Fish Dis 42: 923-934

* Swaminathan TR, Kumar R, Dharmaratnam A, Basheer VS and others (2016) Emergence of carp edema virus (CEV) in cultured ornamental koi carp, Cyprinus carpio koi in India. J Gen Virol 97:3392-3399

*Tadmor-Levi R, Asoulin E, Hulata G, David L (2017) Studying the genetics of resistance to $\mathrm{CyHV}-3$ disease using introgression from feral to cultured common carp strains. Front Genet 8:24

*Wakabayashi H, Huh GJ, Kimura N (1989) Flavobacterium branchiophila sp. nov., a causative agent of bacterial gill disease of freshwater fishes. Int J Syst Bacteriol 39: 213-216

*Way K, Haenen O, Stone D, Adamek M and others (2017) Emergence of carp edema virus (CEV) and its significance to European common carp and koi Cyprinus carpio. Dis Aquat Org 126:155-166

* Zautner AE, Groß U, Emele MF, Hagen RM, Frickmann H (2017) More pathogenicity or just more pathogens? - On the interpretation problem of multiple pathogen detections with diagnostic multiplex assays. Front Microbiol 8: 1210

Submitted: October 2, 2018; Accepted: March 26, 2019

Proofs received from author(s): May 15, 2019 